\title{
ISLAM, PANCASILA AND VALUE SYSTEMS OF INDONESIAN NATIONAL EDUCATION
}

\author{
Martha Catherine Beck \\ Lyon College USA PO.Box 2317. Batesville AR 72503 \\ Email : martha.beck@lyon.edu
}

\section{Irawan}

State Islamic University (UIN) Sunan Gunung Djati Bandung

Jl. A. H. Nasution No 105 Bandung, West Java-Indonesia

Email : Nganirawan72@gmail.com

\begin{abstract}
This paper intends to show that the Pancasila (five principles of state) and the Pillars of Islam (the five religious value system) has synergy to build Indonesia's national education values system. To explore the relation between religion and politics in Pancasila, Martha Beck used Alfred North Whitehead's process philosophy, Carl Gustav Jung's archetypes psychology and Ervin Laszlo's systems theory. To approve that Pancasila and Pillars of Islam has synergy to Indonesia's national education, Irawan used the concept of scientia sacra by Seyyed Hossein Nasr. The results showed that the Indonesian national education system consistently present in a triangular relationship between religion (spiritual humanism), politics (democracy) and cultural (multicultural and tolerance). The relationship manifested in Indonesian National Education System, which is always grounded philosophically and aims at three things; 1) form human who believe, cautious and has noble character; 2) master of science and technology; and 3) actively participate in creating order and peace in the world, even a blessing for the entire universe. Indonesia's national education system could be a new alternative in building a more holistic education systems around the world because considered crucial interconnection between science, religion, interests of state and demands of the global. This is known as a moderate Islamic education.
\end{abstract}

Keywords : Islam, Pancasila, System of Education

\section{ABSTRAK}

[Tulisan ini bermaksud menunjukkan babwa Pancasila (lima dasar bernegara) dan Rukun Islam (lima sistem nilai beragama) saling bersinergi membangun sistem nilai pendidikan nasional Indonesia. Untuk menelaah bubungan antara agama dengan politik dalam Pancasila, Martha Beck menggunakan filsafat proses Alfred North Whitehead, psikologi archetype Carl Gustav Jung dan teori sistem Ervin Laszlo. Untuk membuktikan bahwa Pancasila dan lima Rukun Islam itu bersinergi dengan Pendidikan Nasional Indonesia, Irawan menggunakan konsep 'scientia sacra' Seyyed Hossein Nasr. Hasil kajian menunjukkan bahwa sistem pendidikan nasional Indonesia secara konsisten hadir dalam suatu bubungan segi tiga antara agama (spiritual bumanisme), politik (demokrasi) dan kebudayaan (multikultur dan toleransi). Hubungan tersebut 
termanisfestasikan dalam Undang-Undang Sistem Pendidikan Nasional Indonesia, yang secara filosofis selalu berpijak dan bertujuan pada tiga hal yakni; 1) membentuk. manusia yang beriman, bertakwa dan berakblak mulia; 2) menguasai sains dan teknologi; dan 3) turut aktif menciptakan ketertiban dan perdamaian di dunia, babkan menjadi rabmat bagi selurub alam. Sistem pendidikan nasional Indonesia ini bisa menjadi alternatif baru dalam membangun sistem pendidikan yang lebih holistik di seluruh dunia, karena menganggap penting adanya interkoneksi antara sains, agama, kepentingan negara dan tuntutan global].

Kata Kunci: Islam, Pancasila, Sistem Nilai

\section{INTRODUCTION}

In the year 2012, the entire world is engaged in the next, most inclusive, and most serious "Era of Globalization." We are in the midst of a huge paradigm shift in the way we understand the principles of being, the structures behind the universe, our natural world, human nature, and human culture. People need to grasp the basic principles of the universe, as we now understand them. Everything we experience and observe in contemporary culture is the product of recognizing and tapping into the energy of the universe as we have recently discovered it to exist. We need to have some notion of the scientific foundation for the existence of computers and technology, the cause behind the economic side of globalization. Only by understanding this foundation can we create a new civilization that synthesizes all we know about both nature and culture and provides guidance for how we ought to live. We have been living on the foundation of modern science. This model has been proven inaccurate and destructive. We must change to understanding existence as many layers of interconnected systems.

There are three recent thinkers who all reaffirm the value of religion in our new way of understanding the universe: Alfred North Whitehead, Carl Jung and Ernst Laszlo. Whitehead calls for a new synthesis of religion and science. He knows human beings are driven by both the desire to find the causes behind the natural forces they observe and the desire to live for the sake of something immaterial, some higher vision. Jung's vision of the individuated person, living the fully active and integrated life, is Jung's way of integrating the religious teachings and insights of the past with the need for human beings to find meaningful and purposive lives today. Laszlo points out that the new model of the sciences, systems sciences, affirms the reality of non-material spheres of nature and culture and the need for people to articulate their values and religious traditions in a way consistent with the systems view.

With above in mind, the article will show that the five principles of the Indonesian political philosophy, called Pancasila, should be understood as one example of a model for political leadership and cultural development 
based on the systems view of the universe, whether or not anyone who helped create it was consciously aware of this. The five principles of Pancasila were a response to the history and peoples living in the area that the leaders were trying to bring together into the nation named "Indonesia." The first and most important principle is a religious one; \#1 Belief in One Supreme God. The other four principles connect all other aspects of social and political life to that first principle; \#2 A just and civilized humanity; \#3 Indonesian unity; \#4 A people's democracy led by wisdom through deliberation and representation; and \#5 Justice for all Indonesian People.

Indonesia's constitution differs from the United Nations' Declaration of Universal Human Rights because of its emphasis on religious belief and because it does not use the language of 'rights' to articulate its sense of justice and how to attain it. This article will show that the principles are more consistent with the contemporary systems sciences than are those political documents written during the Enlightenment, such as the United States' Declaration of Independence and Constitution, the political documents of the French Revolution, and the United Nations' International Declaration of Human Rights. Indonesia's Pancasila represents a model better adapted to the worldview behind the sciences and technologies of today. I will mention the Five Pillars of Islam and how the Indonesians combine a population that is $88 \%$ Muslim with a constitution based on religious toleration. This particular aspect of the context within which the Pancasila principles are lived out is, Indonesia's most unique and most important contribution to make to the development of international civilization.

Many Muslims live in anti-democratic, authoritarian nations run by leaders who govern through Islamic Law alone. If those nations' economies are based on a natural resource, like oil, they do not have to adapt to international globalization and do not have to adopt an international model of culture. They can stay mal-adaptive and survive. As time goes on, however, and we actually do what we all know must be done-switch to environmentally sustainable sources of energy - the resources and the rigid culture in these nations will have to change also. The nations under Islamic Law will eventually be brought into the process of globalization based on systems sciences and the systems view of all aspects of culture.

The Indonesian constitution and the history Indonesians make in applying it in their overwhelmingly Islamic society will provide an important model for international development today. Citizens throughout the world, Muslims and non-Muslims, need to know that Muslims can live in a democratic society, with all of its freedoms, and still retain a very serious, pious Islamic way of life. Indonesia has to teach us that lesson, by setting the example. Not only that, this article wants to show that some of the education 
policy in Indonesia derived from religious values are based on the development of democratic civilization that is becoming widespread as the science of nature's grace for all.

Because this article was written by two people then this article is divided into two major parts. The first part presents a concise idea of Whitehead, Jung and Laszlo and discuss the relationship between religion and politics in the Pancasila in the frame of the three thinkers. This section presented by Martha Beck which contained in Contemporary Systems Sciences, Implications for the Nature and Value of Religion, the Five Principles of Pancasila, and the Five Pillars of Islam. The article was published in the Dialogue and UniversalismE Volume 4, Number 1/2013. The text was modified into this paper with the direct approval from Martha Beck, and Brown as the owner of the journal. Part two discusses Islam, Pancasila and the values system of National Education of Indonesia. This section described by Irawan.

\section{DISCUSSION}

Alfred North Whitehead, a major intellectual figure in the 20th century and the founder of process philosophy, claims that religion is a natural and necessary part of every human life and culture. Religion is not simply a nonscientific and even anti-scientific explanation for the same phenomena that science can now explain. Religion is not the accumulation of myths that claim to be facts and that now science has shown to be myths, meaning false. Whitehead claims that religion can adapt to scientific changes in worldview while retaining the power over people and cultures. The expression of those principles requires continual development. This evolution of religion is in the main a disengagement of its own proper ideas from the adventitious notions which have crept into it by reason of the expression of its own ideas in terms of the imaginative picture of the world entertained in previous ages (Whitehead, 1967, p. 189).

Whitehead describes religion as a body of ideas about the ultimate nature and meaning of the universe and of human life. We inherit these ideas from our ancestors, but we must always modify them or they will no longer have any meaning or influence on human thought and action. They form the tradition of our civilization. Such traditional ideas are never static. They are either fading into meaningless formulae, or are gaining power by the new lights thrown by a more delicate apprehension. They are transformed by the urge of critical reason, by the vivid evidence of emotional experience, and by the cold certainties of scientific perception. No generation can merely reproduce its ancestors. This is truer today than ever (Whitehead, 1967, p. $188 \& 1974$, p. 83). 
Jung agrees with Whitehead that religion and science should not conflict. Each has its own sphere of influence and both will persist throughout human history. Jung agrees with Whitehead that religion is concerned with an intuitive grasp of a vision of life beyond mere physical life. Whitehead seems to think religion is a set of ideas about the good life and God. Whitehead seems to think that if intellectuals can rethink religion and articulate their ideas well, they will inspire human beings to live well. Jung is more pessimistic about the human race. Jung's view of the collective unconscious as an underlying and unchanging structure to our instinctual lives is not the same vision as Whitehead. Jung brings back religion as a vital aspect of every culture, but he does so in a different way than Whitehead does. In the past, these spiritual powers have been thought of as living beings, either on earth or in heaven. Now, however, we can recognize them as embedded in and projections from our own instinctual consciousness. Jung rejects both the existence of supernatural personal deities and the worldview of modern science as ways to understand religion and its important function in the human soul and society. Rather, he advocates embracing the old myths and faith tales with a new, non-literal understanding. He argues that religious myths and fairy tales are motivated by the desire to 'educate' the unconscious. The stories have survived for centuries and millennia because they touch the deepest layers of the collective unconscious (Hull, 1969, p. 151).

Jung understands the 'shadow' side of a person as that part of human consciousness connected directly to the most primitive human instincts. Some of our shadow side has been shaped for millennia. We inherit the basic parameters within which we live out our instinctual lives from what has been shaped in the past. When we are born, everything we do and feel is registered in our brains but almost all of it is pushed out of consciousness (Hull, 1969, p. 185). The repressed 'shadow' is not entirely bad, however. On the contrary, it is the source of the greatest human inspiration to create art, science, community, and all of the truly 'inspired' ways people live out their lives (Henderson, 1964, p. 118).

The instinctual unconscious can only be educated through the study of myths, tragedies, poetry, and other art forms that express the drives of the collective unconscious. He developed a new kind of psychology to help patients learn how to educate their 'shadow side' (Whitmont, 1978, p. 165). The shadow is a moral problem that challenges the whole ego-personality, for one cannot become conscious of the shadow without considerable moral effort. To become conscious, it involves recognizing the dark aspects of the personality as present and real. This act is the essential condition for any kind of self-knowledge, and it therefore, as a rule, meets with considerable 
resistance. Indeed, self-knowledge as a psychotherapeutic measure frequently requires much painstaking work extending over a long period (Champbell, 1971, p. 145).

With the shadow, people will not only deny the dark desires within themselves but will also project their own unacknowledged desires onto others. They will blame other people for the very faults that exist within themselves, which Jung calls 'shadow projection (Champbell, 1971, p. 146). If the shadow can be recognized and transformed, it can be a source of deep self-knowledge and inspiration. Those who have assimilated the shadow have a passion for wisdom and justice because they know how important it is to educate others and develop well-organized communities to prevent a personal or collective regress to a more primitive level of existence (Jung \& von Franz, 1964, p. 210).

The goal of human life is to integrate consciousness and unconsciousness into the 'Self' or 'individuation' to refer to people who have integrated the shadow into their lives, all aspects of life; physical, emotional, spiritual, intellectual, and instinctual. Our most spontaneous intuitions, the ways we react spontaneously to difficult situations, have reached the highest level of maturity. People who have achieved selfhood act both spontaneously and creatively in every situation (Chodorow, 1997, p. 68 \& 82). A person 'in touch' with their unconscious has a running 'conversation' with the way the instinctual side 'emerges' as a 'voice' that wants the conscious person to act a certain way (Chodorow, 1997, p. 58).

The world's religious history and mythology provide the most profound examples of people who have achieved Selfhood. Jung cites examples from very different cultural contexts and periods that nonetheless all refer to a mystical experience of unity within. In Taoism, Buddhism, Islam, various schools of Christianity, and elsewhere, religious seekers claim to have an experience of a higher level of consciousness. Religious leaders such as Buddha, Jesus, and Muhammad are inspiring examples of individuated people. Religious mythology provides stories of the spiritual journey from brokenness to wholeness and examples of the Great Man, the one who is whole (Chodorow, 1997, p. 68-202).

Because religious language is symbolic language for Jung, not meant to be taken literally, Jung thinks the religious literature of the past is one subclass of the broader class of art. Great art is art that activates the collective unconscious. It exposes whatever a culture has repressed, so citizens can bring any particular repressed drive into consciousness and trigger the collective desire to avoid making the particular mistake of being driven by that type of destructive instinct (Stein, 1969, p. 82-83). 
Ervin Laszlo's description of the implications of systems theory for understanding religion and the religious attitude toward life is also compatible with Jung and the kind of theory Whitehead encouraged future thinkers to set forward, based on the new view of the universe given to us by the sciences. Laszlo explains why the systems view of the world does not imply the kind of radical division between religion and science that was so prevalent when modern science was the dominant paradigm for understanding nature and human nature. Laszlo points out the change in the 'imaginative picture' of the world provided by systems sciences. The systems view accepts the nature and importance of religion when it is correctly understood (Laszlo, 1996, p. 12-13). However, the promise of a worldview derived from the classical tenets of modern science is increasingly questioned. Alienation and anomie are on the rise, and adherence to an atomistic concept offers scant relief. There is an urgent need to go beyond classical science's view of the world, to a more integrated but no less tested and testable view (Laszlo, 1996, p. 12-13).

Laszlo's position on religion is similar to Whitehead's and Jung's: religion and culture cannot be reduced to the model of materialistic, atomistic science. Ancient thinkers have a model that needs to be recovered in a version that fits with current understandings of reality. Instead of reducing human beings to mere physical creatures, systems thinking recognizes them as the most complex combination of multiple systems: material and non -material. They have emerged from the natural systems that evolved before they did (Laszlo, 1996, p. 60). On the systems view there is no separation between the natural and the cultural worlds. The systems view of the underlying structure of the material world has changed our view of the relation between nature and culture (Laszlo, 1996, p. 68).

On the systems view, human beings are unique. "It is relatively easy to tell whether any organism possesses reflective consciousness by noting whether it has developed a language and other symbolic modes of expression and communication, and whether it can transcend the limits of the here-andnow by making plans not directly triggered by actual stimuli. Man alone passes this test (Laszlo, 1996, p. 69-70). Human evolution does not reduce human beings to 'mere' animals, physical creatures trying to survive. On systems theory, human culture has evolved out of nature but is a completely different kind of reality. Evolving humans learned how to recognize patterns in their experiences. Human beings develop languages to communicate their thoughts, leading to the formation of culture (Laszlo, 1996, p. 69-73).

Over time, human beings develop more and more complex societies, to the point where we are now living in societies that depend on an unsustainable level of exploitation of natural resources. Human beings 
naturally need to develop values. Values define cultural man's need for rationality, meaningfulness in emotional experience, richness of imagination, and depth of faith. Yet some values lead to self-destruction, both individually and collectively, and hence need to be reexamined and changed. Laszlo claims that the rejection of ancient myths in favor of modern science was based on a mistaken view of both myth and science. It led to the separation of culture from nature, reason from emotion, a great mistake in the formation of values and of culture (Laszlo, 1996, p. 75-76).

On the systems view, everything in the universe must be understood from the point of view of 'values' in some sense. Every action is directed toward a goal and achieving that goal is its 'value.' There are no facts apart from some kind of thing moving or changing for the sake of realizing some capacity and creating reality, some inherent value (Laszlo, 1996, p. 80). Human beings possible to distinguish between describing the values people have, what ideas of good drive their behavior, and normative values, the kinds of behavior that are most likely to lead to the goal of self-fulfillment, the ultimate goal of all behavior and all other values. Descriptive values are those we observe, while "normative values (or value norms) are things we discover by examining human characteristics and pointing to those values which could lead people to fulfillment. Hence normative values are not described but postulated, "they are creations of the inquiring intellect [but not arbitrary] (Laszlo, 1996, p. 81)." The goal of a well-lived life is simply to become as completely human as possible. Our humanity is a multifaceted, multilayered system. The systems view is a kind of humanism (Laszlo, p. 1996: 87).

Systems thinkers point out that we have exploited the earth's resources to the point of destroying both ourselves and life on earth as we know it. It is time for a different imaginary picture in our minds of the earth. The earth is an interconnected living being, a Gaia system, a 'mother' who we must care for if we are to survive. We need to recognize this underlying system. Laszlo embraces religion as one important way to get ourselves oriented to the universe, to the natural world, to ourselves, and to each other. The root meaning of 'religion' is to bring together (Laszlo, 1996, p. 88).

Religions would not need to sacrifice, or even compromise, their cherished tenets to make a unique contribution to this shift. They would only need to draw on their own humanism and ecumenism to encourage creative thinking in regard to the elaboration and extension of their traditional insights. There is, obviously, a significant humanistic and ecumenical component in every great religion. Islam has a universal and ecumenical aspect: Tawhid, the religious witness 'there is no god but Allah,' is an affirmation of unity as Allah means divine presence and revelation for all 
people. The great religions could draw on such ecumenical and humanistic elements to nurture a creative elaboration of their fundamental doctrines, supporting and promoting the shift to the new holistic consciousness (Laszlo, 1996, p. 89).

When religion is understood in this broader way, it can easily be integrated into the systems view of reality. The larger reality of the cosmos, need not be confined to the empirical sciences only. The process of cosmos is all-embracing, and has a spiritual in addition to a physical dimension, by recognizing and celebrating the world's evolutionary self-creation. Religions could promote this process of recognition in each individual..... They could celebrate the evolution of the noosphere on Earth as the next, and especially significant, phase in the world's evolutionary self-creation....the self-creating universe is our larger self-our primary sacred community (Laszlo, 1996, p. 90).

Religion that ignores our current destruction of the planet and our collective self-destruction is out of touch with what we know to be the basic structures of reality. Because of the crisis in our relationship to the ecosphere, to the Gaia system, Laszlo calls for a renewal of religious ideas. Religious renewal always came in the wake of civilizational crises. Mohammed proclaimed his mission in an epoch of disorder in Arabia; and Baha'ullah wrote in confinement imposed by a moribund Ottoman Empire. Today, an epochal need for a creative extension of the traditional fundaments of the great religions, to complete and complement the rational worldview that is already emerging within the new sciences. With an alliance between science and religion, the shift to a systemic and wholistic worldview would be reinforced. Both through reason and through feeling, contemporary people could be brought into closer harmony with each other, and with their environment. The cultures we can build for ourselves may be manifold, but they must remain compatible with the structured holarchy of nature. We can build culture beyond these limits only at our immediate peril (Laszlo, 1996, p. 90-93).

\section{The Systems View in Relation Between Religion and Politics}

The view of religion emerging from Whitehead, Jung, and systems theory is that we need a resurgence of religion especially in the promotion of a certain way of living as 'the will of God/the gods.' We need a model for political life that integrates religion with political power. There would be no single official state religion. The state would tolerate different religious traditions. Do not explicitly point to Islam as a backward and barbaric religion, without knowing much of anything about it. One would think that such 'progressive' thinkers would distinguish between facts and rumors 
about a cultural tradition that they had not experienced directly. One would also think that an intellectual would not judge a religious tradition according to the behavior of its so-called 'disciples,' since 'disciples' who identified with the various branches of Christianity slaughtered each other for centuries over differences in doctrine and in the name of 'God's will.' The inconsistency between the belief in using scientific method of the Enlightenment thinkers and this particular prejudice is stunning. Jung would call this a clear example of 'shadow projection.' Locke and Hume think of Islam and Islamic culture as 'the other,' as an evil demon. Christianity, on the other hand, is necessarily good, or is inherently much better.

This kind of idealization of one's own tribe, religion, etc. and demonization of someone one identifies as 'other' is exactly what Jung claims we ought to always be aware of and avoid in our personal and political lives. This projection of the dark shadow is particularly evident in, and particularly destructive in relation to, our political lives. Jung saw the various nations of Europe demonize each other, each blaming the other(s) for what was a complicated network of cause-effect. A systems thinker would think of the situation as a holistic system that was systematically destroying itself. Jung watched as the Germans demonized the Jews, using them as a scapegoat. After (World War Second/WWII) ended and the mistakes were supposedly acknowledged, Jung watched as the same sick and dangerous projection of the dark shadow took over the world during the Cold War. The entire world was caught up in being either 'for' Communism and authoritarianism or 'for' freedom, democracy, and human rights. Both sides oversimplified the insights of the other. Both committed great atrocities in the name of protecting the world from the evil demon of the 'other.'

After the Cold War, the world witnessed a few years of relief from such a black-and-white division of the entire world before it set in again. Since September 11, 2001, the world has once again divided itself into 'them' and 'us.' On one side are the "terrorists" and on the other side are the "lovers of freedom." Rulers in oil-rich Muslim nations easily maintain their power by distributing some of their wealth to the poor and uneducated and by convincing them of the evils of Western society and culture. Westerners blame Islam. The deeper cause is our own addiction to oil. Westerners will not admit that these 'demons,' the terrorists, were born from the greed and ignorance of the West. The American economy depends on exploiting natural resources around the world, buying oil from Muslim nations, and believing that Americans have a 'God -given right' to exploit nature and have an affluent lifestyle. Leaders of mid-East nations rich from oil are happy to reinforce Islamic beliefs by condemning American greed and arguing that 
Islam is clearly a superior religion because its adherents are self-controlled and generous.

When Americans desire a higher standard of living than people in any other society in human history, Muslims around the world can convince their followers and convert non-Muslims based on the idea that Muhammad was the 'Seal of the Prophets.' On this view, Muhammad was called by God to finish Jesus's work. Jesus did not work, marry, raise a family, or exercise political power. Jesus asked people to 'love God and your neighbor as yourself,' but did not give posterity a model of how that love can be exercised in the context of the complications of adult life. Muhammad finished the work by setting a model of how to live a complete life in obedience to God. He was a businessman, a husband, a father, and a political leader. As long as Westerners are indeed materialistic, and even as long as they are perceived to be, Islam will be a strong influence in international cultural life. The more Americans insist on using oil and importing it from Muslim nations, the more likely it will be that Islam will gain members and power around the world.

The animosity between the disciples of the Religions of the Book, Jews, Christians, and Muslims, as it is being played out in the confrontation between Israel and Palestine, could easily lead to a world war with untold destruction. Each religious tradition focuses on blind 'belief' in the different words in their Holy Books about the meaning of life on earth. Hindus, Buddhists, and all others are supposed to accept behavior that is the antithesis of any authentic religious life justified by words in books they do not accept as the most important religious texts. Even if such a 'holy war' does not occur, the continued use of fossil fuels will lead to wars for resources throughout the world. The colonial era led to wars between the colonial powers and the people they subjugated. Their primary motive was greed: exploiting the natural and human resources in the colonies to increase their national wealth. The next phase of globalization has and will continue to lead to wars between nations in the contest for natural resources, the same motive as the colonial era.

The views of religion and the relation between religion and the nature of reality as Whitehead, Jung and Laszlo express them show that there is a great cultural need to reunite politics and all other aspects of civilized life with an understanding of 'religion' that is international and interdenominational, and that binds people together in all their personal, social, political, cultural relationships and in their relationship with the natural world. 


\section{Indonesia's Pancasila in the Relation Between Religion and Politics}

In 1945, Indonesia first broke away from being controlled by the Dutch. After the Dutch broke two different treaties, they finally gave up and in 1949 Indonesians were able to form their own constitution and govern themselves. Their goal was to set up a political system that included all the characteristics of a democracy: elected officials, a balance of powers, free speech, free trade, the rule of law, equal representation under the law, and all the basic freedoms from government interference. Indonesians also applied the meaning of democratic equality and equal rights to the development of a public school system and public health care, through a system of taxation that redistributed some wealth. Indonesians also had to develop government agencies to collect taxes and provide education, health care, transportation, and other services the citizens decided that a tax-paying Indonesian citizen deserves to receive from the government. Indonesians wanted a society that functioned internally much like the societies of the colonial powers claimed to function internally. They did not want to use the same ideology or worldview that the colonial powers used to oppress them. They wanted to articulate a new way of understanding all aspects of human culture, a way that fit with their own history and culture and that would be most likely to lead to a society of thriving, middle-class citizens.

Indonesians did not want to define political life the way John Locke and the US Declaration of Independence did. They did not want to hold their politicians accountable as just or unjust only on the basis of whether they were allowing citizens to become as prosperous as each individual decided was rational and best. They did not want to trivialize the impact of religious belief on the ability of citizens to live together well as citizens under a common body of laws. However, they also knew well the power of religious bigotry. They knew the way the Dutch used religious beliefs to justify their superiority, to justify fear of the 'other,' and to justify oppression and violence which otherwise would clearly go against the commandments of any religious tradition.

Instead of imitating the West or negara-negara Timur Tengah pada umumnya, Indonesians did what Whitehead, Jung, and Laszlo bahkan Nasr recommend: they redefined the relationship between religion and politics. The five principles of Pancasila, the founding document of the nation of Indonesia, are as follows: 1) Belief in One Supreme God (this includes Hinduism, Buddhism, Islam, Christianity and Confucianism); 2) A just and civilized humanity; 3) Indonesian [internal] unity; 4) A people's democracy led by wisdom through deliberation and representation; and 5) Justice for all Indonesian people. 
In writing Pancasila, Indonesians knew they were developing a new paradigm for understanding all aspects of culture and a new model for a democratic society. They were rejecting the Enlightenment worldview and the ideology of individual and collective rights. In complete opposition to Enlightenment political ideology, Indonesians chose to begin with religious belief. As Whitehead, Jung, and Laszlo all recommend, they focused on the most universal, humanistic, and ecumenical aspects of the six dominant religious traditions practiced by their citizens. They wrote a founding document that assumes any citizen who adhered to the real spirit of religion in any tradition will live together peacefully with people from a different tradition. They even included Christianity, both Protestant and Catholic, the religion of their oppressors, because many Indonesians are Christians. They wanted to make clear to their citizens and everyone else that they could distinguish between the real message of Christianity and the perverse way it was abused by the Dutch and all the colonial powers to maintain and even increase their power. They distinguished between the essence of religion and its great value in developing human culture and the great harm done when religious traditions are perverted.

As Whitehead, Jung, and Laszlo point out, religion is a highly complex product of human culture. It arises from the human need for meaning and purpose over and above the need to survive. This need is so great that people sacrifice survival needs and their lives in order to gain meaning. As Jung points out, because religion focuses on views of the ultimate meaning in life that cannot be proven through scientific method, religion can be used as a way to demonize others and idealize oneself. It is easy to project the dark shadow onto others in the name of 'God's will' because no one has any concrete proof of what an immaterial God wants from us. Instead of avoiding the issue altogether, as Westerners did, the Indonesian constitution addresses it as the first priority. Citizens of Indonesia are asked to live out their religious beliefs in ways that promote a free and open society. Pancasila demands that Indonesians will treat each other as equals, not apart from or in spite of their religious beliefs, but because of those beliefs. According to Pancasila, no one is truly 'religious' unless they live justly in relation to fellow citizens. No legitimate religious believer will try to take advantage of a fellow citizen on the basis of religious conviction.

The Indonesian model of religious belief should be called 'spiritual humanism' because it assumes that human beings naturally recognize powers greater than themselves. Further, human beings cannot be fully human unless they are motivated by some idea of goodness and justice that goes beyond meeting basic survival needs. Whitehead's, Jung's and Laszlo's positions are also types of spiritual humanism. 
Indonesia is on the forefront, then, for developing a new model for human culture in the age of systems sciences and the next wave of globalization. Indonesians have chosen to show to the world that religious belief leads inevitably to justice. Beginning with Principle \#1: Belief in One Supreme God. Pancasila is based on the view that the other four principles follow inevitably from such a belief.

Principle \#2: A just and civilized humanity links the tradition of humanism to belief in God. There is no opposition between the religious understanding of human nature and the human condition and the affirmation of our humanity. This, also, reflects a complete rejection of the ideology and history of Western culture. The Indonesians knew that the Biblical story of Adam and Eve, accepted by Jews, Christians, and Muslims alike, has often been used to justify authoritarian governments. People are assumed to be sinners by nature. They therefore must have authoritarian leaders and institutions, especially political ones, to keep them from destroying themselves and each other. They have to be taken care of by someone else, someone with power. The history of Western culture is a history of people killing each other in the name of what they called 'God,' the 'God' of Christianity and Judaism. Indonesians reject such behavior as religious in any sense. They want to set up a paradigm in which religious belief is the very foundation for democratic society and a civilized humanity.

By contrast, most of the United States Declaration of Independence is a pseudo-scientific proof. The Declaration uses facts to support its conclusion that the King of England is a tyrant and deserves to be overthrown. It uses material well-being or lack thereof as the fundamental criteria for determining whether a political leader is just or unjust. Material well-being includes security of person and possessions and individuals freedom of choice to speak and behave as one likes without government interference. The Declaration uses science to justify political revolution. It is a very individualistic, secular and materialistic document. The Founding Fathers of Indonesia clearly had no interest in imitating this.

Principle \#3: Indonesian unity implies necessarily that Indonesians will protect each other and create one unified state, even when they belong to all of the world's great religions. Muslims will live together with Hindus, Buddhists, Confucians, Jews, and Christians. This is not a document based on religious toleration, the willingness to 'put up with' people you know are wrong just for the sake of maintaining social order. Rather, this document shows that unity between members of these religions is a religious mandate. One cannot be an honest member of any of these religions without desiring the well-being of members of all the others. 
Principle \#4: A people's democracy led by wisdom through deliberation and representation. This principle points out that no one religion makes its believers superior to others. No one religion can be used to justify a disproportionate number of members of one religion gaining political and social advantage over others. People vote for who they think will rule best. They should not base their vote on the candidate's religion. If the country is $88 \%$ Muslim, chances are that the vast majority of elected officials will be Muslim. But there is no natural or necessary connection between being Muslim and being better at ruling. The people are being educated to talk to each other about a candidate's experience and record as evidence of his or her ability to rule well. Unfortunately, as happens everywhere, too often the determining factors include friends with the money to pay for campaigns and other ways political life is corrupted. The point, though, is that the constitution trains people to focus on what matters. The corruption cannot enter because the constitution itself promoted favoritism, even when religion has so often been used to proclaim one's moral and political superiority and, hence, one's competence as a ruler.

Principle \#5: Justice for all Indonesian People. This principle points out that religious life cannot be separated from social and political activism. Claiming to believe in God necessarily means treating other people justly. One cannot claim to love another person without also voting for leaders who structure and run their institutions so that collective goods and services, including money, education, and health care, are distributed to all and according to what each needs. Unity, Principle \#3, represent a basic trust and good will between all citizens. Justice, Principle \#5, implies follow through from good will to good institutions and policies. Setting up these institutions, rather than protecting individuals' rights, is the standard by which politicians will be judged. If they refuse to use their power and influence in ways that promote collective well-being, they are neither pious believers in a just and good God or competent and just rulers of their own people.

In every way, therefore, the ideas set out in the five principles of Pancasila are all parts of a whole. The whole is a new model for culture, as Laszlo defines culture. Laszlo says that in a time of crisis, cultures need to reexamine the underlying basic values and structures of the universe as a whole and human culture within it and have to reframe their entire culture to respond to the crisis. Laszlo points out that culture is a holistic level of reality that goes way beyond the mere need to survive. Today, the human race could destroy itself and nature as we know it. The model of Pancasila goes a long way to prevent two of the worst threats to global self-destruction: human arrogance toward nature, the worst sin in any religious tradition, and the 
confrontation between Islam and the two other Religions of the Book, Judaism and Christianity.

\section{Islam and Pancasila}

Another great contribution of Indonesia to international culture is the implicit union of the Five Pillars of Islam with the Five Principles of the Constitution. It is no accident that there happen to be five main points in the Constitution and five main pillars of Islam.

The first Pillar of Islam is Shahada: Testifying to God's One-ness: The declaration "There is no God but Allah and Muhammad is His prophet." The Constitution was clearly designed to imitate, but also clearly differ from, the first pillar of Islam. While the Constitution makes clear that six world religions are considered legitimate in terms of belief in God, the Constitution also makes clear that the spirit of the Indonesians should be very much like the true religious spirit of any human being: belief in an ultimate first principle that gives life sacred and ultimate meaning. Whitehead, Jung and Laszlo could all agree to this basic principle while not believing that what is being referred to is a personal God, much less the specific God of the Islamic faith.

The second principle of Islam is prayer, Salat. Muslims are required to pray five times each day. This principle and the behavior connected to it should be applauded by anyone who is concerned with the development of culture today. Prayer is a continual reminder that there is a power beyond human beings. Today, one might think of that power as the force of nature that drives toward higher and higher levels of complexity, as Laszlo does. One might think of the power of the unconscious which acts as a power that gives life meaning and 'feels' like a power beyond oneself, as Jung does. The Muslim view of God and the need for prayer is probably most like Whitehead's view.

Religion is the vision of something which stands beyond, behind, and within, the passing flux of immediate things; something which is real, and yet waiting to be realized..... The immediate reaction of human nature to the religious vision is worship.....The vision claims nothing but worship; and worship is a surrender to the claim for assimilation, urged with the motive force of mutual love (Whitehead, 1967, p. 192).

The third principle of Islam is Zakat: Giving charity. No society can survive unless the citizens are generous. Plato and Aristotle went so far as to describe greed, the desire for more than one's share, as the worst political evil. This desire leads inevitably to a gap between the rich and poor. The rich have no limits to their desires and have the power to structure the society to 
serve them, even though the institutional structure might be officially 'democratic.' The poor have no time to participate in social and political life but must stay focused on what they need to do to survive. They cannot develop their capacity for deliberation.

No structuring and restructuring of institutions or electing and reelecting of leaders in all sectors of society will lead to justice and good will unless people are generous. All major religions condemn greed. When examining the harmful effects of greed on human society and the promotion of generosity by all major religious traditions, it makes sense to connect religion with politics. The modern paradigm assumed that if everyone stays focused on their own individual prosperity they will create wealth that promotes the well-being of everyone else. Plato, Aristotle, and the great religious leaders knew this was folly. The rich would only find ways to control the social and political system to promote their own interests. The poor would only get poorer. Animosity and distrust between the rich and poor would increase, undermining social stability and preventing a higher level of cultural life.

The fourth principle of Islam is Sawm: Fast. No society can survive unless the citizens exercise self-control in relation to physical pleasure such as hunger and sex. Hunger, especially, is continually with us and must be kept under control. The habit of fasting reminds citizens that they depend on God/the universe first and then upon the culture as a whole to provide food. Fasting reminds citizens to avoid excess consumption and even the desire for excesses. Self-control in relation to physical pleasures is internalized. The habit of fasting could never be required by political leaders, but it does strengthen the moral character of citizens, which improves their ability to think clearly about how to organize their society and distribute limited resources, especially something as fundamental and immediate as food.

The fifth principle of Islam is Hajj: Pilgrimage to Mecca. This requirement links Indonesian Muslims to Muslims around the world. If they go to Mecca, Indonesian Muslims might have the opportunity to engage in dialogue with Muslims who live in Islamic societies governed by rigid (Shar'ab) Islamic Law. They could then compare their society with more authoritarian Islamic societies from the point of view of people who live there. Most Muslims will never come to Indonesia, so going to Mecca is one way Indonesians can tell them about their great democratic society with $88 \%$ Muslim citizens. Muslims from the nations that are now making the change from authoritarian to democratic societies, including Tunisia and Eqypt, could get information and inspiration from Indonesians. The gathering of Muslims from around the world in Mecca should be applauded rather than 
feared by Westerners. It could lead to an increase in humanistic and ecumenical Islam and a decrease in authoritarian and intolerant Islam. Indonesian Muslims have a crucial contribution to make in this process.

\section{Impact on The Value Systems of Indonesian National Education}

Selain Whitehead, Jung dan Laszlo, Nasr juga mengemukakan bahwa science harus melibatkan studi tentang kosmos yang memperhatikan prinsipprinsip metafisika dan spiritual secara konsisten. Nature a possesses a spiritual meanings of the utmost importance with which every integral spiritual tradition is concerned in one way on another, although the emphasis on this dimension of reality has not been the same in various tradition over the centuries. There is a need to come to know of this spiritual significance of nature and any treatment of sacred science. It must include a treatment of the spiritual massage which nature provides through her rhythms and harmonies, forms and movements, through her symbols and the grace wich emanates from the Origin through her varigated manifestations (Nasr, 2005, p. 60).

Nasr said that science deals with various domain of nature in addition to the psyche of man and other metaphysical principles including the symbolism, which derive from the Nature of God. The life of nature not only displays harmony and order but also laws which make the harmony and order possible. The laws of nature are but the laws of God for His creation, the Syarìah of each order of the existence, to use of Islamic term. It has its roots in the Quran, the very Word of God, which is the central theophany of Islam. The message of the Quran is in a sense a return to the primordial message of God to man. It addresses what is primordial in the inner nature of men and women; hence Islam is called the primordial religion (al-dinn alhanif). As the "Primordial Scripture," the Quran addresses not only men and women but the whole of the cosmos. The cosmic dimension of the Quran reffered to the ontological Quran (al-Qur'ân al-takwīîi) as distinct from and complementing the composed of "written" Quran (al-Qur'ān al tadwinīi). The Quran refers to the phenomena of nature and events wthin the soul of man as āyāt (literally signs or symbols) Allāh, vestigia Dei, a term that is also used for the verses of the Quran. In an deeper sense, āyāt is all things (Muhīt) (Q.S. Al-Fātihah: 126). So, God is the real 'environment' (al-Muhìt), which to remain aware of sacred quality of nature (Nasr, 2005, p. 60).

The views of religion and the relation between religion and the nature of reality as Whitehead, Jung and Laszlo express show that there is a great cultural need to reunite politics and all other aspects of civilized life with an understanding of 'religion' that is international and interdenominational, and that binds people together in all their personal, social, political, cultural 
relationships and in their relationship with the natural world. Nasr asserts that this effort must be made in global, either by Western countries and the Eastern countries or third world (Nasr, 2005, p. 69-71). The conclusion of this paper will point out that Indonesia's founding political ideology, as expressed in the five principles of Pancasila, is one model for how to unite religion with politics and how to unite both religion and politics with all aspects of life, within a nation, between nations, and in the relationship between nature, human culture, and the systems of education throughout the world.

In Nasr opinion, the Five Pillars of Islam (arkān al-Islām) asserts that in Islam the gaining of a livehood and the provision of material need are stressed and are in fact basic to the Shari' ah, but even these worldly activities (al-dunyā) are judged praiseworthy only in relation to man's final end or the other world (al-ākhirah), the Islamic balance between the spiritual and material aspects of 'amal al-shālih (better human life action) (QS. An-nahl: 30). In the context of Pancasila, that is Islamic society. Islamic society is one in which the individual is related to an organic social manifold within which he find meaning and support. Islamic society is based neither upon individualism, in which the individual loses his inner freedom and is faced with the danger of the stultification of his creative powers through regimentation and uniformity. The value systems of such, affects the relationships between man and society, man and nature, and finally man and God (Nasr, 1990, p. 117-118).

Nasr asserts that this effort must be made in global, either by Western countries and the Eastern countries or third world (Nasr, 2005, p. 69-71). The conclusion of this paper will point out that Indonesia's founding political ideology, as expressed in the five principles of Pancasila, is one model for how to unite religion with politics and how to unite both religion and politics with all aspects of life, within a nation, between nations, and in the relationship between nature, human culture, and the systems of education throughout the world.

According to Nasr, the Quran asserts that God has power over all things. These scriptual statements must not be understood only in the usual theological sense of alluding to God's infinite power. They also refer to God's nature as the All-Possibility and confirm in other language the Quranic verse, "In His hands is to be found the dominion (malakūt) of all things" (QS. Saba': 83). All of them, however, would be happy to live in a culture that follows the principles of Pancasila, as long as the rulers use their power for the well-being of the ruled and have the skills necessary to know best how to achieve this goal (Nasr, 2005, p. 6). 
Indivisibility between the value systems of Islam and Pancasila in Indonesian impact on the determination of policy and the system of the national education. If studied carefully, various education policy in Indonesia has always been based on religious values and culture of Indonesia.

Preambule of the Constitution of 1945, as the nation's major Indonesian constitution mandates that the Indonesian government should seek to "protect the people of Indonesia and the entire country of Indonesia, and to promote the general welfare, the intellectual life of the nation and participate in the establishment of a world order based independence, abiding peace and social justice (UUD. 1945. pdf, p. 1)". Article 31 paragraph 3 of the 1945 Constitution mandates that the Indonesian government should establish and conduct a national education system, the increasing faith and piety and noble character in the context of the intellectual life of the nation. In verse 5 it is stated that the government to advance science and technology with upholding religious values and national unity for the progress of civilization and the welfare of mankind. Article 32 states that advance the state of the Indonesian national culture in the midst of world civilizations, with freedom of society in preserving and developing cultural values. Under the state constitution, the Indonesian government should run a national education system of Indonesia based on Pancasila values, especially the first principle of promoting faith and piety as well as other principles were formulated in the preamble of the 1945 Constitution which is aimed at educating the nation participated the establishment of world order.

The first pillar of Islam, creed, not only demanded that Muslims should faith in God but also must believe in the prophethood of Muhammad. One reason Muhammad was a smart, fathānah. In the modern context of intelligence can be acquired through education, master of science and technology. Such use must be addressed in order to carry out the order of the world. This is reflected in the spirit of Haj and Zakat. Whitehead, Jung, Laszlo and of course Nasr agreed with the integration between religion and civilization.

Because the Indonesian national education system should be based on the Constitution (UUD RI 1945) and basic state (Pancasila) then in UUSPN (Law on National Education System) Indonesia in 2003 stated that the function of the Indonesian national education develop skills and character development of civilization dignified nation in order to educate life of the nation. While the goal is to develop the potential of students to become a man of faith and fear of God Almighty, noble, healthy, knowledgeable, skilled, creative, independent, and become citizens of a democratic and responsible (Article 3 of UU RI No. 20 Th., 2003). 
The principles of education in Indonesia is based on values such as; 1) democratic, equitable, non-discriminatory and uphold human rights, religious, cultural and national diversity; 2) systemic unity, openness and multimakna; 3) the process that last a lifetime; 4) example and willingness to develop creativity; 5) the development of a culture of reading, writing and numeracy for all people; and 6) involve community participation in controlling the quality of education services (Chapter III of UU RI No. 20 Th., 2003).

In the context of the philosophy of Islamic education, national education system Indonesian constitution derived through statehood always lead to the formation of 'imtak' (faith and piety) as well as the mastery of science and technology (science and technology). Because the Indonesian National education is a conscious and deliberate effort to create an atmosphere and an active learning process in developing the potential of students to have a good spiritual strength of religious, self-control, personality, intelligence and noble character, faith and devotion then education is the core system, curriculum, Indonesian educational programs and activities (Tafsir, 2012, p. iv-v).

The concept of faith, piety and science, the Indonesian Islamic education terminology derived from the values of the pillars of Islam and Pancasila are the five. Although the provision of education in Indonesia are generally managed by two departments of the Ministry of Education and Culture and the Ministry of religion, but the same goal of improving human dignity Indonesia knowledgeable and believe in god.

According to Nasr which is also in line with Whitehead, Jung and Laszlo, 'Indonesian-Islamic' education had to be concerned with the whole being of the men and women whom it sought to educate. Its goal was not only the training of the mind but that of the whole being of the person. That is why it implied not only instruction or transmission of knowledge (ta'lim), but also training of the whole being of a student (tarbiyyah). The teacher was not only a mua'llim, a transmitter of knowledge, but also a murabby, a 'trainer of souls and personalities' (Nasr, 1990, p. 123).

\section{CONCLUSION}

Indonesia, like any other nation, cannot 'save the world' alone. At the moment, Indonesian 'development' is taking the same self-destructive route as is still the dominant model throughout the world: the exploitation of natural resources for corporate gain and increased national prosperity. Indonesians know the problems with this model, however, because changes in the earth's climate hit them directly. Very few Indonesians would deny the reality and destruction of climate change. Very few would deny that human 
behavior is a large factor in the destruction of the earth's Gaia system and that the situation can change if human behavior changes. Indonesians know they must connect their religious lives to respect for the Gaia system. Hopefully, they will soon be able to control the direction of their development and find a way to prosper economically without the continual exploitation and unsustainable depletion of their natural resources. China, India, and Western nations are the greatest consumers of what Indonesia has to offer. At the moment, Indonesia cannot afford to turn them down. Either the world's culture will change, or everyone will go under. Indonesia is not wealthy enough to take the lead in saving the planet. Indonesia greatest contribution to the wellspring of ideas is in its founding document, Pancasila, and in its model of Islam. Indivisibility between the value systems of Islam and Pancasila in Indonesian impact on the determination of policy and the system of the national education. The various education policy in Indonesia has always been based on religious values and culture of Indonesia.

It is written in the Constitution of 1945 and the foundation of the state of Indonesia, Pancasila. Thus, the Act of the Republic of Indonesia Number 20 of 2003 on National Education System, as a rule below of the Pancasila and the 1945 Constitution consistently present a triangular relationship between religion (spiritual humanism), politics (democracy) and cultural (multicultural and tolerance) in organizing educational activities. The relationship manifested in Indonesian National Education System, which is always grounded philosophically and aims at three things; 1) form human who believe, cautious and noble character; 2) master of science and technology; and 3) actively participate in creating order and peace in the world, even a blessing for the entire universe.

\section{BIBLIOGRAPHY}

Campbell, Joseph. (Ed.). (1971). The Portable Jung. New York: Penguin Books. Carl Jung \& von Franz, M. L.. (1964). "The Process of Individuation." In Man and his Symbols, editors 158-229. Garden City, New York: Doubleday \& Co.

Chodorow, Joan. (Ed.). (1997). Encountering Jung: Jung on Active Imagination in Joan Chodorow. Princeton, N. J.: Princeton University Press.

Henderson, Joseph L. (1964). Ancient Myths and Modern Man. In Carl Jung \& M.-L. Von Franz (Ed.), Man and His Symbols. Garden City, New York: Doubleday.

Hull, R. F. C. (Trans.) (1969). Psychological Types. In The Collected Works of C. G. Jung. Vol. 6 of the Bollingen Series XX, 510-23. Princeton: Princeton University Press. 
Hull, R. F. C. (Trans.) (1969). The Archetypes and the Collective Unconscious. In The Collected Works of C.G. Jung. Vol. 8, 9, 11, and 15 of the Bollingen Series XX. Princeton: Princeton University Press.

Jung, Gustav, Carl \& von Franz, M. L. (Ed.). (1964). "Science and the Unconscious." In Man and His Symbols, 304-10. Garden City, New York: Doubleday \& Co.,

Laszlo, Ervin. (1996). The Systems View of the World: A Holistic Vision for Our Time. Cresskill, NJ: Hampton Press, Inc.

Nasr, Hossein, Seyyed. (1990). Traditional Islam in the Modern World. London, New York: Routledge.

Nasr, Hossein, Seyyed. (2005). The Need For A Sacred Science. UK: Curzon Press, Taylor \& Francis e-Library.

Stein, Leopold (Ed.) (1969). Experimental Researches. In The Collected Works of C. G. Jung. Vol. 2 of the Bollingen Series XX. Princeton: Princeton University Press.

Tafsir, Ahmad. (2012). Core Pendidikan Indonesia. Media Pendidikan Jurnal Pendidikan Islam, Vol. XXVII, No. 1.

Undang-Undang Republik Indonesia Nomor 20 Tahun 2003 Tentang Sistem Pendidikan Nasional.

Whitehead, Alfred North. (1967). Science and the Modern World. New York: Free Press.

Whitehead, Alfred North. (1974). Religion In The Making. New York: New American Library.

Whitmont, Edward C. (1978). The Symbolic Quest: Basic Concepts of Analytic Psychology. Princeton, N. J.: Princeton University Press. 